\title{
Mating Types Analysis of Magnaporthe oryzae Populations by Molecular Methods
}

\author{
Soma Samanta, Urmila Dhua*, Shubhransu Nayak, L. Behera, A.K. Mukherjee
}

Division of Crop Improvement, CRRI, Cuttack-753006, Odisha, India

\begin{abstract}
Rice blast is a devastating disease which is caused by the heterothallic fungus Magnaporthe oryzae. Compatible sexual recombination which occurs between two $M$. oryzae strains of different mating types, can enhance genetic variability. Assessment of mating type alleles is used as a marker to measure population diversity. Forty six isolates of $M$. oryzae were collected from infected rice leaves from various ecosystems of coastal Odisha, India, and the mating type analysis using molecular markers was carried out. MAT1-1 mating type was dominating in all the ecosystems and MAT1-2 was found to be present in uplands as well as in irrigated fields. Both mating types could be found in the same field in irrigated ecosystem. The disease spread was very fast vertically as well as horizontally in those fields resulting in blast lesions looking as 'green islands (gi) produced in senescence leaves', and MAT1-2 was found to be associated with all gi lesions. Consequently, the management of the disease in those plots was very difficult. Interestingly, ribosomal RNA IGS region could not be amplified in MAT1-2 isolates but consistent amplification was obtained in MAT1-1 mating type isolates.
\end{abstract}

Keywords: IGS region, $m$. oryzae, mating type, oryza sativa, rice.

\section{INTRODUCTION}

Rice (Oryza sativa L.) supplies approximately $23 \%$ of the per capita energy for six billion people worldwide [1]. Rice blast, caused by Magnaporthe oryzae is a serious disease responsible for yield loss to the tune of $80 \%$ s [2, 3]. Each year, this disease is estimated to destroy enough rice that could feed more than 60 million people [4].

Magnaporthe oryzae B. Couch (anamorph Pyricularia oryzae Cavara; synonym Magnaporthe grisea (Hebert) Barr), is a heterothallic fungus, meaning the population comprises of two distinct mating types (MAT1-1 and MAT1-2) and the sexual reproduction is possible only between the two opposite mating types $[5,6]$. This fungus is considered as highly variable and high degree of pathogenic variation (pathotypes) is observed in the field [8,9]. Sexual reproduction can enhance and influence the genotypic variability of $M$. oryzae populations where the recombinant progenies may have new capability to infect different host cultivars. Both MAT 1-1 and MAT 1-2 are idiomorphs of a single mating type locus Mat [10]. Assessment of mating type alleles has been used as a marker to measure population diversity in this pathogen $[7,11]$.

Conventional approach to determine mating type in the pathogen population depends upon the appearance of mature perithecia in a cross between known tester and an unknown strain on culture media which is time consuming and

*Address correspondence to this author at the Division of Crop Improvement, CRRI, Cuttack-753006, Odisha, India; Tel: +91-9337122834: Fax: +916712367663; E-mail: udhua.crii@gmail.com requires high technical expertise [9, 12-14]. PCR amplification methods using Mat gene specific primers are a rapid method to explore the mating type population of $M$. oryzae [15-17].

In the current study $46 \mathrm{M}$. oryzae isolates (from coastal Odisha, India) were studied for mating type analysis by Mat gene specific molecular markers. In addition, we have also attempted the amplification of the intergenic spacer (IGS) region as this is one of the most rapidly evolving regions in the genome [18].

\section{MATERIAL \& METHODS}

A total of $46 \mathrm{M}$. oryzae isolates, used in the current investigation were isolated from blast lesions produced on leaves collected from various ecosystems of coastal Odisha, India. Fourteen isolates were from rain-fed upland fields, 21 isolates were from Uniform blast nursery at CRRI, Cuttack and 11 isolates from farmer's fields with irrigation facilities (Table 1). M. oryzae associated with blast lesions were isolated by a selective isolation method [19]. Lesion quality of samples was assessed [20]. Isolates were grouped numerically on the basis of lesion color and mating type by NTSYS Pc [21].

\section{Genomic DNA Extraction}

M. oryzae cultures were grown in OM broth (oatmeal broth medium; i.e. oatmeal $30 \mathrm{~g}$, water one lit.). Cultures of 14 days old were used for DNA extraction. Genomic DNA of M. oryzae was extracted according to Liu et.al. [22] with following modifications. Mycelia was ground with $1 \mathrm{ml}$ of 
Table 1. Passport data and mating type analysis of Magnaporthe oryzae isolates from coastal Odisha by molecular methods.

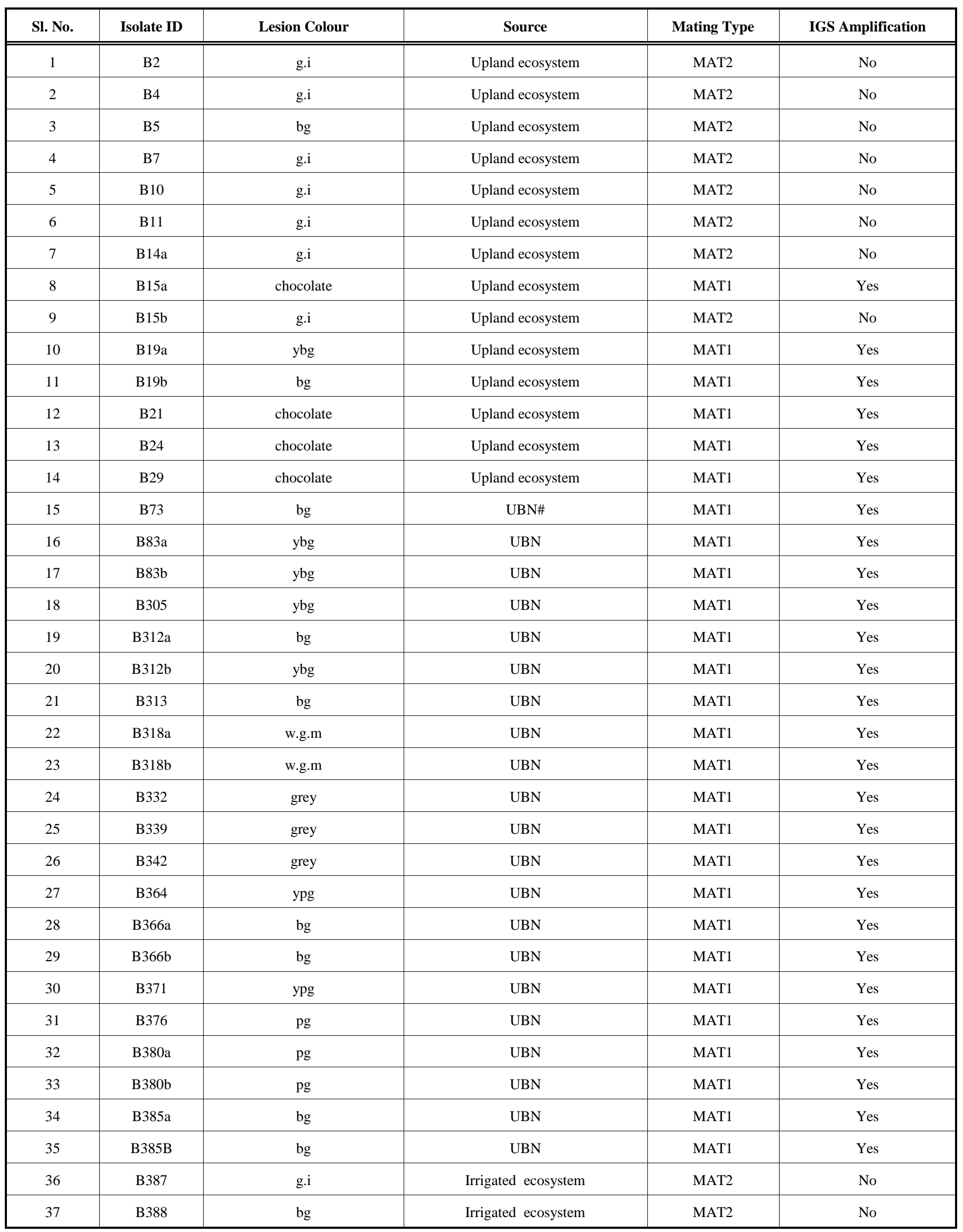




\begin{tabular}{|c|c|c|c|c|c|}
\hline Sl. No. & Isolate ID & Lesion Colour* & Source & Mating Type & IGS Amplification \\
\hline 38 & B389 & bg & Irrigated ecosystem & MAT2 & No \\
\hline 40 & B391 & ybg & Irrigated ecosystem & MAT1 & Yes \\
\hline 41 & B392 & ybg & Irrigated ecosystem & MAT2 & No \\
\hline 43 & B394 & ybg & Irrigated ecosystem & MAT1 & Yes \\
\hline 44 & B395 & ybg & Irrigated ecosystem & MAT1 & Yes \\
\hline 45 & B396 & ypg & Irrigated ecosystem & MAT2 & No \\
\hline 46 & B397 & grey & Irrigated ecosystem & MAT1 & Yes \\
\hline
\end{tabular}

*g.i- green island; bg-brown grey; ybg-yellow brown grey; ypg-yellow purple grey; pg- purple grey; w.g.m-whitish with grey margin; [Dhua, 1998], \#UBNUniform Blast Nursery.

extraction buffer (400mM Tris-HCL pH8.0, $150 \mathrm{mM} \mathrm{NaCl,}$ $60 \mathrm{mM}$ EDTA pH8.0, $1 \%$ SDS) and mixed with $100 \mu \mathrm{l}$ of $3 \mathrm{M}$ potassium acetate $(\mathrm{pH} 4.8)$ and then centrifuged. To the supernatant $500 \mu \mathrm{l}$ of chloroform: isoamyl alcohol (24:1) was mixed and centrifuged. The aqueous phage was collected and mixed with equal volume of isopropanol and centrifuged. The supernatant was discarded and DNA pellet was saved and then washed with $70 \%$ ethanol. After air drying DNA pellet was redissolved in $1 \mathrm{X}$ TE. To remove RNA the DNA solution was treated with RNaseA for $30 \mathrm{~min}$ at $37^{\circ} \mathrm{C}$. RNaseA was denatured by incubating at $60^{\circ} \mathrm{C}$ for 1 h. Quality of DNA was checked on $0.8 \%$ agarose gel and quantity of DNA was estimated by spectrophotometer (Varian, Cary100 BioUV-Visible Spectrophotometer).

\section{Amplification of Mat Gene and IGS Region}

Mating type genes matl-1 and matl-2 were amplified according to [15] using following primer pairs:

(MAT1-1 F 5'TCAGCTCGCCCAAATCAACAAT3')

(MAT1-1R 5'ACTCAAGACCCGGCACGAACAT3')

(MAT1-2 F 5'GAGTTGCCTGCCCGCTTCTG3')

(MAT1-2 R 5'GGCTTGGTCGTTGGGGATTGT3')
PCR was performed in a $50 \mu$ l reaction mixture containing $60 \mathrm{ng}$ of DNA, 1X PCR buffer with KCL, 1.5 $\mathrm{mM} \mathrm{MgCl} 2,10$ pico moles of forward and reverse primers, $0.2 \mathrm{mM} \mathrm{dNTPs}$, and $1 \mathrm{U}$ of Taq DNA polymerase, in a thermocycler PTC 100 (MJ Research). Thirty cycles of amplification were performed in a PCR program of initial denaturation at $94{ }^{\circ} \mathrm{C}$ for $5 \mathrm{~min}$. Each cycle consisted of a denaturation step at $94{ }^{\circ} \mathrm{C}$ for $30 \mathrm{~s}$, annealing temperature at $55^{\circ} \mathrm{C}$ for $30 \mathrm{~s}$ and an extension step at $72{ }^{\circ} \mathrm{C}$ for $1 \mathrm{~min}$, with a final extension at $72{ }^{\circ} \mathrm{C}$ for $5 \mathrm{~min}$. The amplified products were fractioned on $1 \%$ agarose gel, visualized by ethidium bromide staining and documented in Syngene G Box Gel Documentation system.

The IGS region was amplified according to Kumar et.al. [23] using the primer pair LR12R F 5'GAACGCCTCTAAGTCAGAATCC3' and InvSR1R R5' ACTGGCAGAATCAACCAGGTA 3'.

\section{RESULTS}

Approximately 809 bp amplicon was obtained corresponding to MAT1-1 locus with about $70 \%$ of the isolates Fig. (1). Rest 30\% tested positive for MAT1-2 locus with an amplicon size of 940 bp (Fig. 2). About 20\% isolates were from green island producing blast lesions, $24 \%$ were

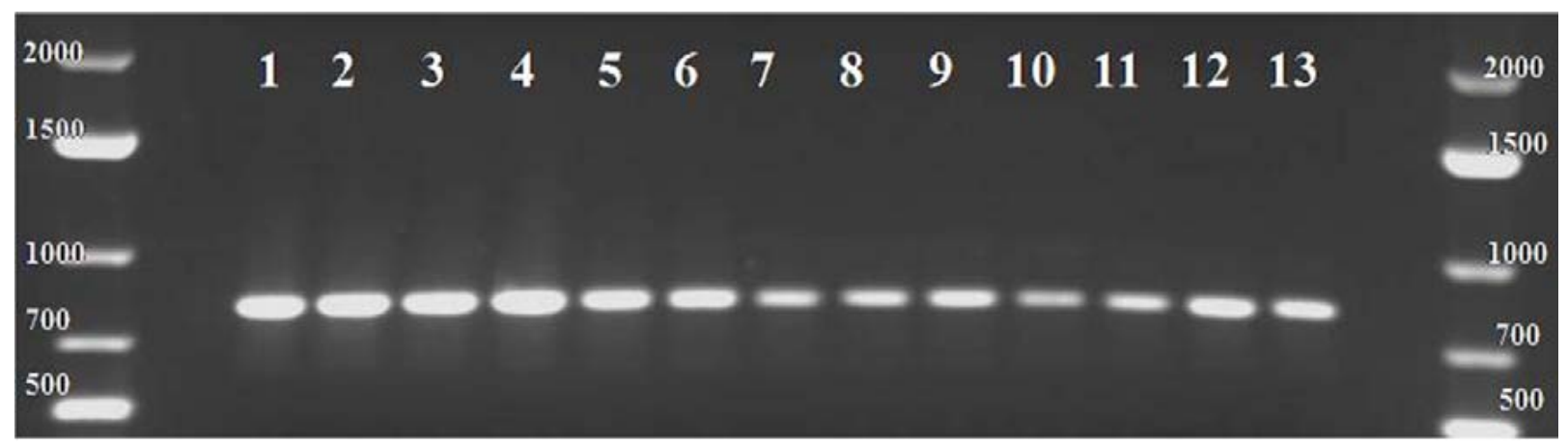

Fig. (1). Amplification of MAT I-1 mating types of $M$. oryzae population by MAT1-1F and MAT1-1R primers.

$1=\mathrm{B}-15 \mathrm{a} ; 2=\mathrm{B}-19 \mathrm{a} ; 3=\mathrm{B}-19 \mathrm{~b} ; 4=\mathrm{B}-21 ; 5=\mathrm{B}-24 ; 6=\mathrm{B}-29 ; 7=\mathrm{B}-73 ; 8=\mathrm{B}-83 \mathrm{a}$;

$9=\mathrm{B}-83 \mathrm{~b} ; 10=\mathrm{B}-305 ; 11=\mathrm{B}-312 \mathrm{a} ; 12=\mathrm{B}-312 \mathrm{~b} ; 13=\mathrm{B}-313$. 


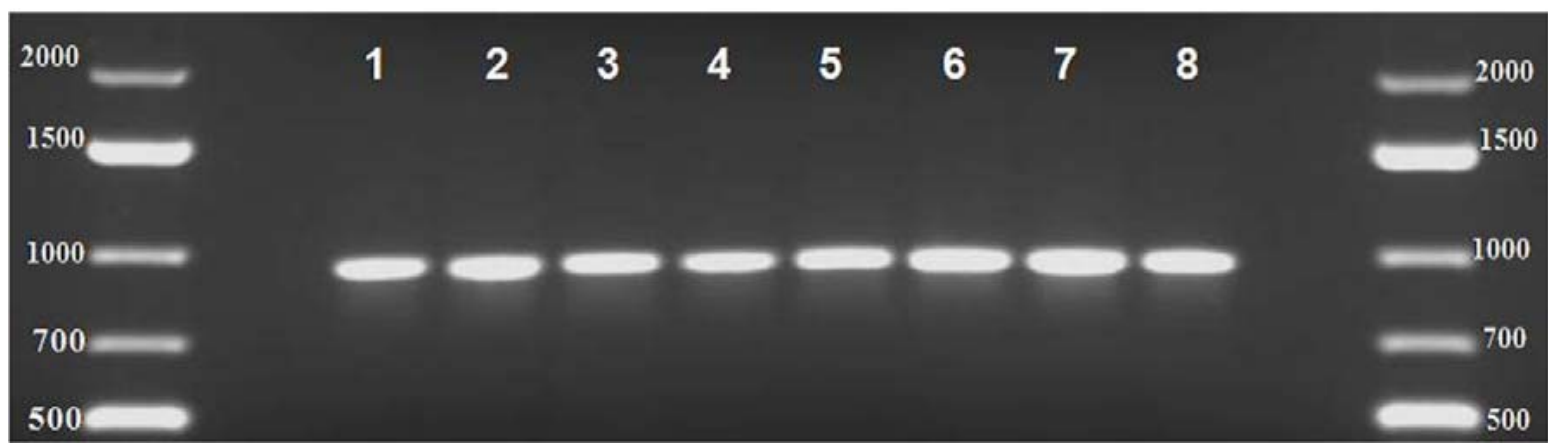

Fig. (2). Amplification of MATI-2 mating types of $M$. oryzae population by MAT1-2F and MAT1-2R primers. $(1=\mathrm{B}-2 ; 2=\mathrm{B}-4 ; 3=\mathrm{B}-5 ; 4=$ B-7; 5= B-10; 6= B-11; 7= B-14a; 8= B-15b).

from bg lesions, 9\% from chocolate colour lesions, $11 \%$ from grey lesions, $6 \%$ from pg lesions, $4 \%$ from whitish grey lesions, $19.5 \%$ from ybg lesions and $6 \%$ from ypg lesions. This grouping on the basis of lesion colour has been clearly depicted from the dendrogram constructed by NTSYS (Figs. 3 and 4) It was interesting to note that all the isolates from gi blast lesions were of MAT1-2. However 35\% MAT1-2 isolates in present study were also from ypg /bg/ybg. MAT11 was not present in gi lesions.

\section{Distribution of Mating Populations in Various Locations}

\section{(i) Upland Ecosystem}

Both mating types were present in the samples from upland fields. MAT1-2 mating type was present in $57 \%$ cultures which were isolated from blast lesions where infected portions of leaf produced green islands and didn't senesce, while un-infected parts of leaf senesced [24]. The MAT1-2 was also isolated from one big broad brown grey lesion (Table 1; Figs 3 and 4). In blast infected samples from uplands, the MAT1-1 was present in M. oryzae cultures associated mostly with avirulent 'yellow brown grey' and chocolate lesions.

\section{(ii) Uniform Blast Nursery (UBN)}

The seeds supplied by co-ordinating centre were grown in UBN and all the samples collected from UBN i.e. brown grey (bg), yellow brown grey (ybg), yellow purple grey (ypg), purple grey (pg) and whitish with grey margin (w.g.m) yielded MAT1-1 mating type (Figs. 3 and 4).

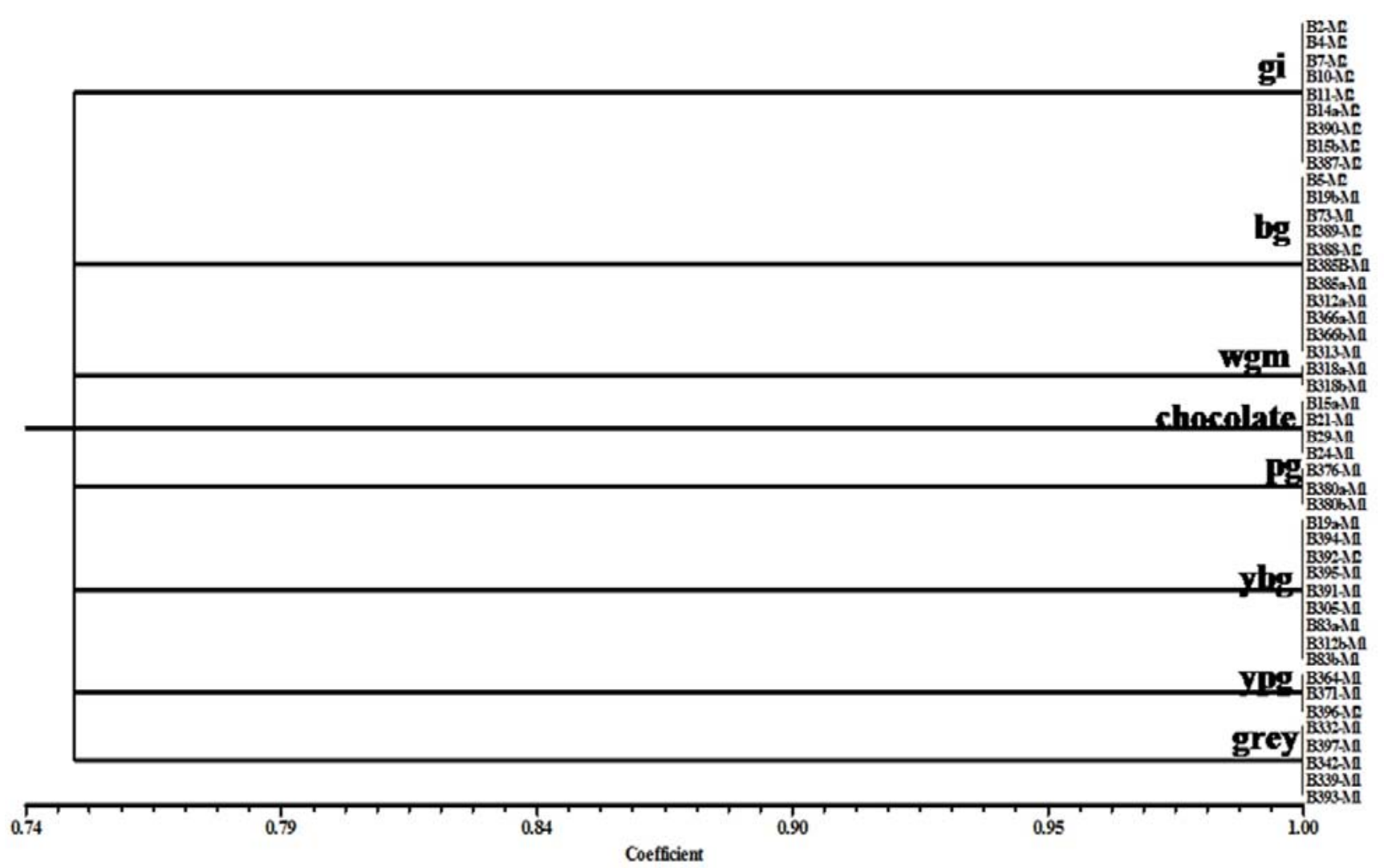

Fig. (3). Grouping of isolates on the basis of lesion colour. 


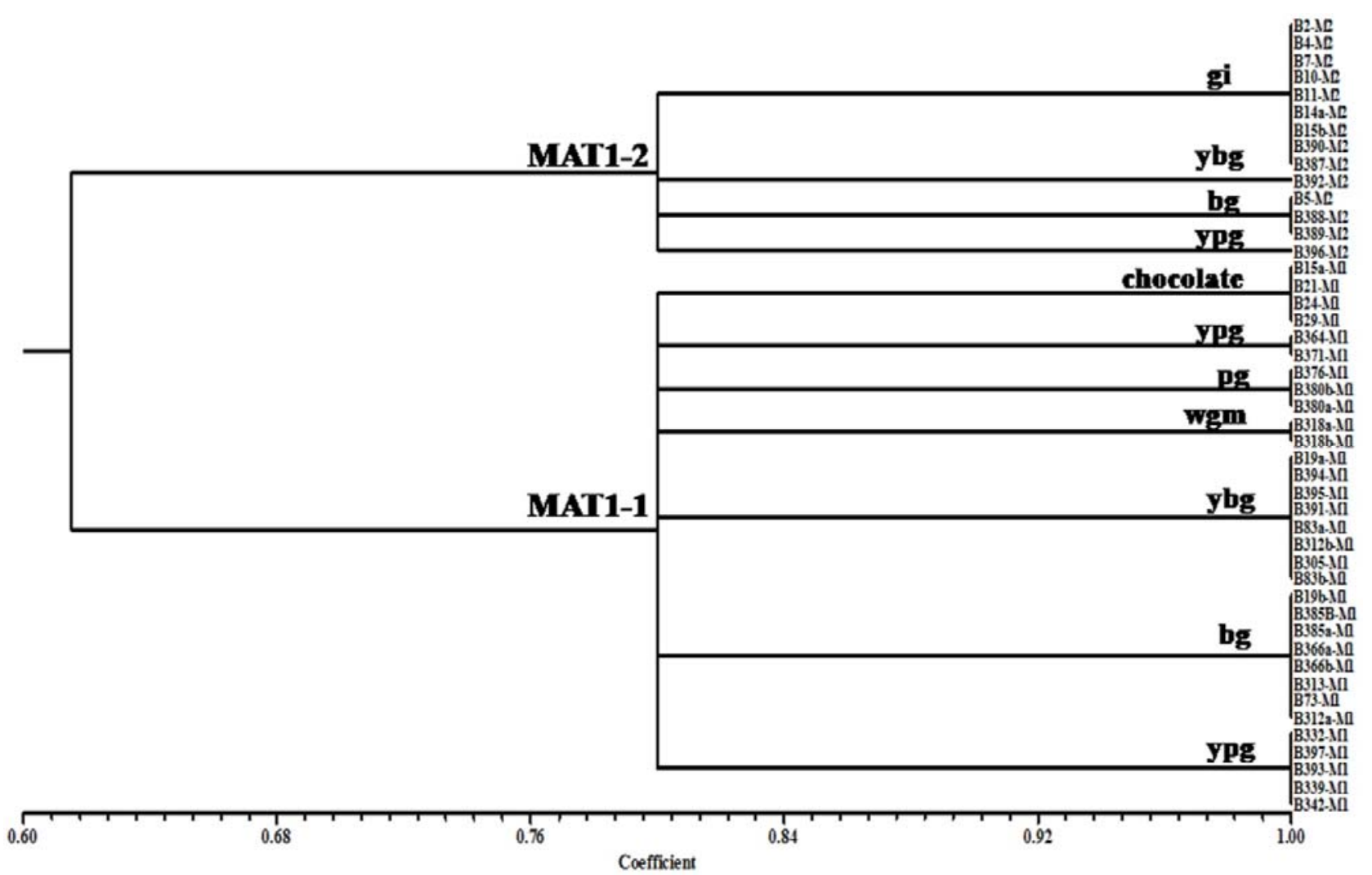

Fig. (4). Grouping of isolates on the basis of mating type. MAT1-1 MAT1-2.

\section{(iii) Irrigated Ecosystem}

Severe blast infection was observed in fields of irrigated ecosystem included in this investigation. Chemical control measures were not effective and the disease spread rapidly in those fields. Both mating populations were observed in the same field. MAT1-2 was found in 55\% samples. MAT1-1 mating type was isolated from grey, ybg and ypg blast lesions. MAT1-2 was observed from 'green islands produced in senescence leaves' or the ypg /bg / ybg lesions possessing thin margin and thick broad grey centre.

\section{Amplification of IGS Region in Various Mating Types}

It was interesting to note that all the isolates classified as MAT1-1 mating type were amplified by IGS specific primers LR12R - InvSR1R resulting in an amplicon size of approximately $3.3 \mathrm{~kb}$, whereas no amplification could be obtained from MAT1-2 populations (Fig. 5).

\section{DISCUSSION}

Analysis of mating type can provide an estimation of genetic diversity among $M$. oryzae populations from rice. Bao-Hua et al. [16] compared the PCR method and the standard strain GUY11 / KA3 mating type assays and there was a good consensus (95.1\%). They suggested PCR based mating type detection method to be more feasible, quick and simple. Same set of primers were used in the present study.

In the samples analyses in the present investigation, MAT1-1 was the dominating mating type in all the ecosystems of coastal Odisha. Using the same primer pair, Dong-mei et al. [17] studied 141 isolates and it was found

\section{MAT1-2}

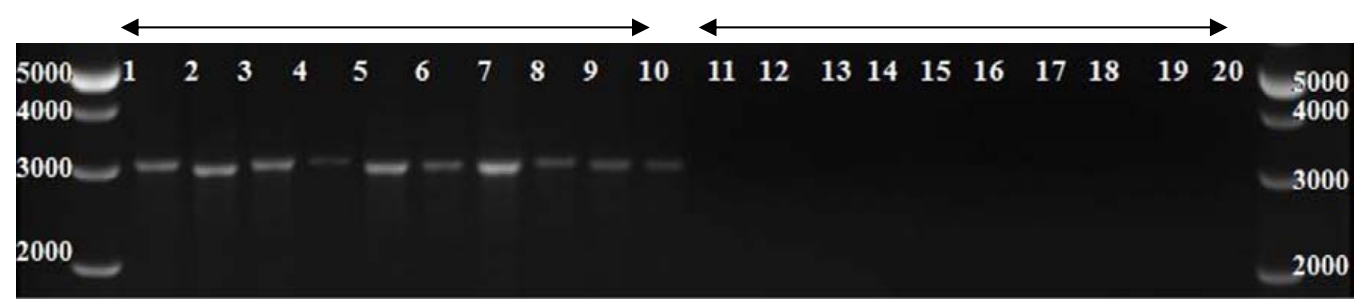

Fig. (5). Amplification of IGS region of MAT1-1 and MATI-2 population by LR12R and InvSR1R. $(1=29 ; 2=\mathrm{B} 73 ; 3=\mathrm{B} 83 \mathrm{a} ; 4=\mathrm{B} 83 \mathrm{~b} ; 5=$ $\mathrm{B} 305 ; 6=\mathrm{B} 312 \mathrm{a} ; 7=\mathrm{B} 312 \mathrm{~b} ; 8=\mathrm{B} 313 ; 9=\mathrm{B} 318 \mathrm{a} ; 10=\mathrm{B} 318 \mathrm{~b} ; 11=\mathrm{B} 2 ; 12=\mathrm{B} 4 ; 13=\mathrm{B} 5 ; 14=\mathrm{B} 7 ; 15=\mathrm{B} 10 ; 16=\mathrm{B} 11 ; 17=\mathrm{B} 14 \mathrm{a} ; 18=\mathrm{B} 15 \mathrm{~b}$; $19=\mathrm{B} 387 ; 20=\mathrm{B} 388)$. 
that $19 \%$ of the samples belonged to MAT1-1 and $17 \%$ to MAT1-2. Urak et al. [11] found 160 of 168 isolates tested to be MAT1-1 in North Central California. In a survey of 467 $P$. grisea rice isolates from 34 countries in Europe and Africa, only mating type MAT 1-1 was found [13]. Zarrinnia et al. [7] found no MAT1-2 isolate among 100 Iranian populations.

MAT1-2 was found to be present in uplands as well as in irrigated fields during the present study. The presence of both mating types in same field in irrigated ecosystem was reflected in the aggressive behaviour of the pathogen. The disease spread was very rapid in those fields resulting in blast lesions as 'green islands produced in senescence leaves' and making the management of the disease challenging. These findings support the earlier observations of Kumar et al. [9] where the populations from the Himalayas were analyzed. They suggested a possible occurrence of sexual recombination in this region. A high MAT1-2 population (83\%) was observed by Bau-Hua et al. [16] among 150 field isolates in rice from Fujian province of China. The size of PCR product produced by MAT1-1 / MAT1-2 in this study was similar to the bands observed by Bau-Hua et al. [16].

The IGS region that separates the repeated ribosomal genes appears to be the most rapidly evolving spacer region among fungi [25]. The entire IGS region can be amplified using primers anchored in the 3' end of the LSU gene e.g., LR12R and 5' end of the SSU RNA gene e.g., invSR1R [26, 27]. The ability and superiority of IGS regions as a highly variable marker for detecting compatible mating spores of mushroom species have been demonstrated in Ferula sinkiangensis [28], Schizophyllum commune [29], Hebeloma cylindrosporum [30] and Pleurotus cornucopiae [31, 32]. In present study, the IGS region did not amplify in MAT1-2 isolates but isolates possessing MAT1-1 were amplified. The correlation of lesion colour and the mating type indicates that there is a relationship between these two as evident from the dendrogram obtained using lesion colour (Fig. 3), as well the dendrogram using both lesion colour and mating type (Fig. 4). This observation suggests that the virulence of the pathogen could be predicted from the lesion colour, as reported earlier by Dhua [33] and while scoring the blast disease the colour of the lesion should be considered [20].

\section{CONFLICT OF INTEREST}

The authors confirm that this article content has no conflicts of interest.

\section{ACKNOWLEDGEMENTS}

Authors are grateful to The Director, Central Rice Research Institute for providing necessary facilities and Dr. P.K. Mukherjee, Scientist G, Bhabha Atomic Research Centre, Trombay, Mumbai, India for kindly going through the MS.

\section{REFERENCES}

[1] Maclean J. Rice Almanac International Rice Research Institute, Los Banos, Phillippines. 1997.
[2] Puri KD, Shrestha SM, Joshi KD, et al. Reaction of Different Rice Lines Against Leaf and Neck Blast Under Field Condition of Chitwan Valley. J Institute Agri Animal Sci 2006; 27: 37-44.

[3] Ou SH. Rice Diseases. 2 $2^{\text {nd }}$ ed. Commonwealth Mycological Institute, Kew, U. K. 1985

[4] Scheuermann KK, Raimondi JV, Marschalek R, et al. Magnaporthe oryzae Genetic diversity and its outcomes on the search for durable resistance. The molecular basis of plant genetic diversity, Prof. Mahmut Caliskan [Ed.], ISBN: 978-953-51-0157-4, 2012: InTech.

[5] Couch BC, Kohn LM. A multilocus gene genealogy concordant with host preference indicates segregation of a new species, Magnaporthe oryzae, from M. grisea. Mycol 2002; 94: 683-93.

[6] Talbot NJ. On the trail of a cereal killer: Exploring the Biology of Magnaporthe grisea. Annual Rev Microbiol 2003; 57: 177-202.

[7] Zarrinnia V, Nikkhah MJ, Zadeh HRZ, et al. Fertility Assessment and Mating Type Analysis Reveal the Absence of Sexual Stage in Magnaporthe oryzae Populations in Iran. Sci Series Data Rep 2012; 4: 123-32.

[8] Silva GB, Prabhu AS, Filippi MCC, et al. Genetic and phenotypic diversity of Magnaporthe oryzae from leaves and panicles of rice in commercial fields in the State of Goiás, Brazil. Tropic Plant Pathol 2009; 34: 71-6.

[9] Kumar J, Nelson RJ, Zeigler RS, et al. Population structure and dynamics of Magnaporthe grisea in the Indian Himalayas. Genetics 1999; 152: 971-84.

[10] Kang S, Chumley FG, Valent B, et al. Isolation of the Mating-Type Genes of the Phytopathogenic Fungus Magnaporthe grisea Using Genomic Subtraction. Genetics 1994; 138: 289-96.

[11] Urak RZ, Douhan GW, Wong F, et al. Mating-type distribution of the rice blast pathogen Pyricularia grisea in California. UCR Undergrad Res J 2008; 2: 61-65

[12] Priyadarisini VB, VIJI G, Gnanamanickam SS, et al. Mating type distribution, fertility and pathogenicity of rice isolates of Magnaporthe grisea in four rice growing regions of India. Indian Phytopathol 1999; $52: 28-34$.

[13] Notteghem JL, Silue D. Distribution of the mating Type Alleles in Magnaporthe grisea Populations Pathogenic on Rice. Phytopathology 1992; 82: 421-24.

[14] Hayashi N, Li C, Li JL, et al. In vitro production on rice plants of perithecia of Magnaporthe grisea from Yunnan, China. Mycol Res 1997; 101: 1308-10.

[15] Zheng Y, Zhang G, Lin F, et al. Development of microsatellite markers and construction of genetic map in rice blast pathogen Magnaporthe grisea. Fungal Genet Biol 2008; 45: 1340-47.

[16] Bao-Huaa W, uo-Donga LG, Hai-Minga L, et al. Assessment of Magnaporthe grisea mating type by PCR. J Agri Biotech 2004; 12: 183-7.

[17] Dong-mei L, Hong-Li J, Wen-de L, et al. Studies on mating types of Magnaporthe grisea in Sichuan Province of China. J Sichuan Agri Univ 2005; 23

[18] Mishra PK, Fox RTV, Culham A, et al. Restriction analysis of PCR ampliced nrDNA regions revealed intraspecific variation within populations of Fusarium culmorum. FEMS Microbiol Lett 2002; 215: 291-96.

[19] Dhua U. Selective Method for isolating Pyricularia from Blast Lesions. Curr Sci 1986; 55: 410-11.

[20] Dhua U. Integrated Scoring System for rice blast. Indian Phytopath 1998; 51: 57-60.

[21] Rohlf, FJ. TSYSPc, numerical taxonomy and multivariant analysis system. Version 2.02. Appl Biostat 1990, New York.

[22] Liu D, Coloe S, Baird R, et al. Rapid mini-preparation of fungal DNA for PCR. Journal of Clinic Microbiol 2000; 38: 471.

[23] Kumar M, Shukla PK. Use of PCR Targeting of internal transcribed spacer regions and single-stranded conformation polymorphism analysis of sequence variation in different regions of rRNA genes in fungi for rapid diagnosis of Mycotic Keratitis. J Clinic Microbiol 2005; 43: 662-8.

[24] Dhua U. Association of green island with rice blast lesions and its utility in varietal screening. Curr Sci 1987; 56: 192-3.

[25] Aminnejad M, Babai-Ahari A, Javan-Nikkhah M, et al. Molecular and Pathogenic variation within Iranian Pyrenophora graminea Population; More Polymorphism in IGS Region. AmericanEurasian J Agri Env Sci 2009; 6: 697-704. 
[26] Vilgalys R, Hopple JS Jr, Hibbett DS, et al. Phylogenetic implications of generic concepts in fungal taxonomy: The impact of molecular systematic studies. Mycol Helvet 1994; 6: 73-91.

[27] Lachance MA. Ribosomal DNA spacer variation in the Cactophilic Yeast Clavispora opuntiael. Mol Biol and Evol 1990; 7:178-93.

[28] Zhang, JX, Huang CY, Ng TB, et al. Genetic polymorphism of ferula mushroom growing on Ferula sinkiangensis. Appl Microbiol Biotech 2006; 71: 304-9.

[29] James TY, Moncalvo JM, Li S, et al. Polymorphism at the ribosomal DNA spacers and its relation to breeding structure of the widespread mushroom Schizophyllum commune. Genet 2001; 157: $149-61$.
[30] Guidot A, Lumini E, Debaud JC, et al. The nuclear ribosomal DNA intergenic spacer as a target sequence to study intraspecific diversity of the ectomycorrhizal basidiomycete Hebeloma cylindrosporum directly on Pinus root systems. Appl Env Microbiol 1999; 65: 903-9.

[31] Iracabal B, Labarere J. Restriction site and length polymorphism of the rDNA unit in the cultivated basidiomycete Pleurotus cornucopiae. Theo Appl Genet1994; 88: 824-30.

[32] Avin FA, Bhassu S, Tan YS, et al. DNA Pedigree Tracking to Identify Compatible Mating Partners of pleurotus pulmonarius. J Anim Plant Sci 2014; 24: 89-97.

[33] Dhua U. Relation between colour, size and sporulation ability of rice blast lesions. J Phytopath 1989; 124: 27-30.

(C) Samanta et al.; Licensee Bentham Open.

This is an open access article licensed under the terms of the Creative Commons Attribution Non-Commercial License (http://creativecommons.org/licenses/ by-nc/3.0/) which permits unrestricted, non-commercial use, distribution and reproduction in any medium, provided the work is properly cited. 